\title{
Strategic management in enhancing educational quality (environmental scanning done by the principal at SD N 01 Koto Tangah)
}

\author{
Zizvi Rilian Ramadona ${ }^{1}$, Hanif Alkadri², Sufyarma $\mathbf{M}^{3}$ \\ 123Universitas Negeri Padang, Padang - Indonesia, (rahmifi27@gmail.com)
}

\begin{abstract}
In a school, principal has major contribution to lead better education. It could be assumed that a principal is the center of school policy in order to improve educational quality. Dealing with preceding explanation, a principal officially should conduct an environmental analysis in improving educational analysis. This paper presents the result of a study about environmental analysis conducted by principal of SD N 01 Koto Tangah. Data were obtained through interview, observation and documentation. The respondents were principal, school committee, teachers, and students' parents. This paper revealed that there principal as the top leader of the school has done environmental analysis professionally. Principal involved school committee and society in shaping school vision, mission and school policy. There are two environments namely external and internal. Both of them have been analyzed by principal in order to improve educational quality particularly at SD N 01 Koto Tangah.
\end{abstract}

Keywords: environmental analysis and educational quality

\section{Introduction}

It is widely accepted that school is center of education. In common, a school has several important components which bound one another such as teachers, principal, school, committee, students and society. All of those components cannot be separated partly.

The principal is one of the important people who influence the school success in education and learning process. The principal has responsible to lead and manage school personnel both teachers and officers. The principal gives the instruction and guidance to teachers and officers in order to do their works.

Environment influences the quality of education. Good environment commonly brings good achievement of education quality. Environmental analysis is an observing activity, evaluating, and informing information from internal and external environment toward the principal or key people in the school. 
The results of Environmental scanning are strategic factors based on external environments faced as opportunities and threat. Then, internal environments faced as strengthens and weakness of school resource management. As it is mentioned in previous explanation, a principal should conduct environment analysis to view how effective of school policy, to control rules have been agreed together, to improve education quality. SD N 01 Koto Tangah has a principal who manages and controls internal and external environment. The principal, in later practice is supported by school committee, and society in shaping vision, mission and other future planning.

There are many factors that determine school success at school. The principal should able to plan the best strategic through strategic management. In pursuing educational quality, strategic planning should be formulated by all related environments clearly. In line with education quality, it is widely suggested that principal and school components analyze environment. It is commonly agreed, not all, good environment reflects well managerial and controlling by the principal. To know more, researcher academically tries to discuss deeper about strategic management, in this case is environment analysis.

\section{School Principal}

Principal in simple way could be defined as top leader in a school. School principal several duties such organizing, controlling, and evaluating. A principal is helped by teachers and school committee in ruling the policy. According to Wallace Foundation (2013:4) an effective principal performs five important concepts. (1) shaping a vision of academic success for all students (2) creating climate hospitable to education (3) cultivating leadership in others (4) improving instruction (5) managing people, data and process to foster school improvement. Those important concepts ideally should be internalized into principal horizon. Those five concepts open the gate of success for education. Principal together with school committee and society design school vision and mission. In final steps, principal as a manager manages people, data and process to foster school improvement. On this occasion, she/he conducts environment analysis.

\section{Environmental analysis}

In common sound, environment analysis is an activity that is conducted by principal in analyzing school environment. The term environment consists of physical and non-physical matter. It is conducted in order to improve education quality as well as to manage the school itself.

In broaden explanation; Baldwin (1995:5) alleges that the analysis of school environment must be conducted in a comprehensive and systematic fashion. It is important for all schools and society. It can be implied that a school should conduct environment analysis periodically. By this, the analysis can mirror the quality of education on that school. Environmental analysis should be done comprehensively and systematically. Principal can arrange the step orderly, discuss the policy deeply. All school components are involved in analyzing the environment. It will improve the quality and sustain the school policy.

\section{Environment analysis and education quality}

Field of education with all its complexity cannot be described by single liner relation. It means, education cannot stand alone partly. It bounds one element to other. Austin (1991:61) states there are three variables namely: inputs, environment, and outputs. Three of them have interrelationship 
relation. The outputs are affected not only buy inputs but also by environment itself. Environment strongly gives effect to output, in this case education quality.

In particular explanation, Beketova (2016:1) mentions two types of environment: external and internal environment. Both of them give significant effect on quality of education. External environment deals with different variables that is available beyond the school unit boundaries. On the other hand, internal environment deals with organization, function, behavior, and effectiveness. All of those specific factors are exist inside of school boundaries.

\section{Method}

This research used descriptive method by applying qualitative approach where researcher describes and analyzes environment analysis done by principal of SD N 01 Koto Tangah in enhancing educational quality.

Researcher tries to draw research object interactively, to describe various informants' perspective, to dig more deeply the data about strategic management in improving education quality of SD N 01 Koto Tangah.

Data were obtained through interview, observation and documentation. The respondents were principal, school committee, teachers, and students' parents.

To gain valid data, researcher used three technique of data collections namely observation, interview and documentation. Then, to analyze the collected data researcher used technique such as data reduction, data display, data verification.

\section{Result and Discussion}

\section{Internal environment analysis}

1. Teachers and staff

Based on interview have been done by researcher to principal, school committee and society most of teachers and staff work professionally. The teachers do their academic duty such as teaching, guiding, transferring knowledge and evaluating. Educational staffs have done their duty professionally. They always come on time to school and leave school out also punctually. The principal often controls and check the absence of his staff and teachers.

\section{Students}

Students at SD N 01 Koto Tangah are active and smart students. Some of them are accepted in favorite junior high school on their region such Payakumbuh and Agam Regency. Some of students have also followed science competition which had been held in West Sumatera Province. Besides academic achievement, the students also followed non-academic one like football competition.

\section{Students' parents}

Students' parents play important role in improving education quality. Students' parents get involved actively in school activity such as giving donation for school, giving suggestion. Usually at the end of year, the principal invited students' parent to have yearly meeting. They also have roles in designing school vision and mission. 


\section{School equipment and facility}

To improve human index resource, the principle invited competence practitioner and trainer to give seminar for the teachers. One of them is how to use computerize system. Most of teachers have their own laptop. No wondering, they have quite knowledge on recent computer technology. This school has technology facilities like in-focus, laptop, computer and internet network (Wi-Fi).

\section{School culture}

The principal, teachers, staff and students agreed a commitment. Teachers and staff should come on time. Discipline is an important key in this school to improve school quality.

\section{External environment analysis}

1. Building networking to another institution.

Principal builds networking with another institution. On this case, this school works together with health department. Students can enlarge their knowledge about health.

\section{Economics field}

Majority the students' parents are farmer. Principal asks the students to bring their lunch meal from home. It is suggested for students in order to make more effective and efficient. One obstacle appears in surface, students' parents need their children to help their job. So, the students missed the extracurricular activity.

\section{Conclusions}

This article suggests that a new paradigm for enhancing educational quality is applying strategic management that focuses on the purposeful activities by school leaders and members to advance the organization's mission. The principal as the top manager in the school should consider the strategic management in enhancing educational quality.

The strategic management is important done by the school leader. Strategic management will identify the school internal and external environments include strengthens, weakness, opportunities, and threats. The efective strategic will influence school quality.

To take the field of strategic management forward toward mature scientific domain will require a dedicated group of researchers who will work diligently and dogmatically in the field. Hopefully this article lays the foundation for future research and for the integration of the many loosely related theories in the field.

\section{Acknowledgments}

The authors would like to express their thanks to the Editor-in Chief, and journal's anonymous reviewers for their encouragement and valuable comments, and to their colleague who does not mention all briefly 


\section{References}

Austin, A.W. (1991). Assessment for Excellent. New York American Council on Education. McMillan Publishing Company.

Baldwin, Beatrice. (1995). School environment analysis Louisiana Principal Internship.

Beketova, Olga. (2016). External and internal environment of higher school: influence on the quality education. Moscow Technology Institute.DOI 10.105/shconf/2016/201629022003.

Wallace Foundation. (2013). The school principal as leader: Guiding School for Better Teaching and Learning Perspective. (Journal). 